УДК 94. 477. 8 «1920»

ПРОКІП А. В.

https: //orcid.org/0000-0002-7941-9909

МИХАЛЬСЬКИЙ Ю. В.

https: //orcid.org/0000-0002-1504-2604

https://doi.org/10.33577/2313-5603.34.2020.149-160

\title{
ЗРАЗКИ ЗБРОЇ, ЕЛЕМЕНТІВ ОЗБРОЕННЯ ЧАСУ ПОЛЬСЬКО-РОСІЙСЬКОЇ ВІЙНИ 1920 РОКУ З КОЛЕКЦЙ НАЦІОНАЛЬНОГО МУЗЕЮ ІМЕНІ КОРОЛЯ ЯНА ІІІ ТА ЛЬВІВСЬКОГО ІСТОРИЧНОГО МУЗЕЮ
}

Розглянуто події польсько-російської війни 1920 року, проаналізовано характерні особливості предметів зброї та озброєння учасників конфлікту: холодної зброї (багнетів, шабель, шашок), вогнестрільної зброї (гвинтівок різних систем, обрізів), елементів захисного озброєння (штурмових шоломів-касок), які використовувалися у Дієвій армії Української Народної Республіки, польському війську, у російсько-більшовицькій, так званій, «червоній» армії. Особливу увагу приділено зразкам меморіальної зброї, що належала воякам української (шабля отамана Ярослава Воєвідки), польської армій (шабля поручника Яна Казимира Бодновського). Вивчається зброя та озброєння, що походять $з$ місць конкретних боїв польсько - російської війни 1920 року (Клекотів, Бар, Задвір'я).

Ключові слова: музей, зброя, польсько-російська війна 1920 року.

Постановка проблеми та ї̈ актуальність. Після кровопролитних битв Першої світової війни, триваючих визвольних змагань українським землям довелося стати ще й однією 3 головних арен польсько-російської війни 1920 року. У цьому конфлікті основна збройна сила українців - Дієва армія Української Народної Республіки (УНР) на чолі 3 Головним Отаманом Симоном Петлюрою у спілці 3 не дуже надійним союзником, учорашнім ворогом - Польщею на чолі з Юзефом Пілсудським, боролася 3 тоталітарною Російською Радянською Федеративною Соціалістичною Республікою (РРФСР), відстоюючи природне право українців на свободу, незалежність, державність.

Прокіп Андрій Володимирович, кандидат історичних наук, доцент, провідний науковий співробітник Львівського історичного музею, м. Львів.

Михальський Юрій Володимирович, кандидат історичних наук, доцент, завідувач кафедри історії і філософії Львівського торговельно-економічного університету, м. Львів.

(c) Прокіп А.В., Михальський Ю.В., 2020 
Мета та завдання дослідження - розгляд особливостей озброєння, елементів військового спорядження українських, польських та російсько-більшовицьких збройних угруповань, які брали участь у бойових діях 1920 р., на основі матеріалів 3 інвентарних книг Національного музею ім. короля Яна III у Львові та його наступника - Львівського історичного музею (далі ЛІМ).

Аналіз попередніх досліджень. За ці, більш як 100 років, що минули $з$ часу польсько-російської війни 1920 р., іiі причини, перебіг та наслідки уже достатньо повно висвітлені у науковій, науково-популярній літературі. Загальна історіографія питання значна, адже цьому конфлікту присвячена чимала кількість досліджень різних авторів як у Польщі, так і в Україні, Росії. Серед основних праць можна згадати дослідження М. Литвина, К. Науменка, I. Мельника, О. Чубінського та ін.

Однак питання висвітлення особливостей озброєння учасників подій 1920 р. на прикладі зразків з музейних колекцій, на наш погляд, розкрите не повною мірою. До означеної проблеми частково зверталися музейні працівники спочатку Національного музею ім. короля Яна III у Львові, зокрема Р. Менкицький, а згодом ЛІМу - Б. Мельник, О. Роман, І. Свєшнікова, О. Перелигіна у процесі роботи над складанням путівників, каталогів, інвентарних описів предметів.

Джерельну базу дослідження склали, передусім, матеріали фондової групи «Зброя» архіву ЛІМ.

Виклад основного матеріалу дослідження. Події польськоросійської війни сприяли суттєвому поповненню і збагаченню музейної колекції зброї. Ці предмети можна умовно розділити на три групи:

1. Зброя та озброєння, пов'язані з українськими військовими підрозділами.

2. Зброя, озброєння поляків.

3. Зброя російсько-більшовицьких загарбників періоду війни $1920 \mathrm{p}$.

Скласти уявлення про зброю та озброєння українських вояків того часу дозволяє низка предметів з колекції. Цікавим є унтерофіцерський багнет-кинджал українського вояка зразка 1895 р., виготовлений в Австро-Угорщині (Архів ЛIМ: № 3-754). Багнети такого типу використовувалися у комплекті разом 3 гвинтівкою системи Фердинанда Манліхера й були на озброєнні спочатку в 
легіоні Українських Січових Стрільців (УСС) австро-угорської армії, згодом в Українській Галицькій Армії (УГА) та Дієвій армії УНР.

Багнет має прямий, односічний, однодольний клинок. На рікасо 3 обох боків стоять клейма - $з$ одного боку F. G. / G. Ү., а з іншого двоголовий орел (герб Австро-Угорщини). У багнета сталева хрестовина, один кінець iї має кільце, інший загнутий гачком. Рукоятка - 3 дерев'яних обкладинок на двох загвіздках, коричневого кольору, різьблених у гуцульський орнамент та інкрустованих блакитним бісером.

3 одного боку на грифі є накладні літери «УСС», вирізані 3 білого рогу, прибиті мідними цвяшками й інкрустовані блакитним бісером. 3 іншого - вирізьблена монограма $з$ літер «Н» $\mathrm{i}$ «К».

Голівка багнета сталева, зі скошеним нижнім краєм, має пружину 3 кнопкою, паз та скобу, до якої причеплена китиця 3 вигаптуваними вензелем УСС й галицьким левом. Багнет має сталеву піхву з гачком і кулькою на кінці. Загальна його довжина складає 30 см, довжина клинка - 24,9 см (Архів ЛІМ: № 3-754).

Підвищену увагу дослідників завжди викликала не просто зброя, а меморіальні речі, що належали безпосереднім учасникам історичних подій 1920 року, адже вони допомагають краще зберегти пам'ять про людей, які колись ними користувалися. Меморіальні речі є справжніми свідками життя та діяльності знакових осіб.

Таким предметом у збірці ЛІМ $\epsilon$, наприклад, офіцерська шабля (3-1084), що належала Ярославу Воєвідці (1882-1920) отаману УГА, командиру 1-го артилерійського (гарматного) полку УСС. У 1920 р. Я. Воєвідка перебував на службі у підконтрольній російським більшовикам Червоній Українській Галицькій Армії (ЧУГА), окремі підрозділи якої ще до початку головного наступу польсько-українських сил (25 квітня 1920 р.), наприкінці березня-початку квітня почали переходити на бік Дієвої армії УНР.

Я. Воєвідка загинув наприкінці березня 1920 р. у містечку Піщанка біля залізничної станції Попелюхи Балтського повіту Подільської губернії від кулі більшовицького комісара М. Табукашвілі, який пограбував убитого, привласнивши його коня та гроші - 150 карбованців (Кучерук, 2010: 78). Українські вояки з 11-ї (Стрийської бригади) не залишилися у боргу й зуміли 
помститися за безпідставне вбивство популярного командира, учинивши над російським чекістом-мародером самосуд (Литвин \& Науменко, 1991: 161).

Офіцерську, кавалерійську шаблю зразка 1904 р., що належала Я. Воєвідці, виготовили на початку XX століття в АвстроУгорщині. Ця модель перебувала на озброєнні австро-угорської кавалерії упродовж 1904-1918 pр.

Шабля має нікельований клинок слабкої кривини, односічний, а на кінці двосічний. Туп'я розложисте, заокруглене, пересікає кінець клинка, утворюючи ребро. Біля п'яти з леза вибрано трохи металу так, що утворюється поріжок.

Арматура ефесу шаблі - сталева, нікельована. Гард складається 3 широкої акуратної чашки, що переходить у дужку, має два отвори під темляк, вільний кінець опущений. Гриф дерев'яний, обтягнений зміїною шкірою, рубчастий по горизонталі, перевитий крученим дротом, внизу охоплений обоймицею. Гребінь 3 двома боковими лопатями, біля чашки горизонтально насічений, переходить у ковпачок. Піхва сталева, нікельована, з устям, двома гайками і «черевиком». На верхній гайці - скоба, на нижній кільце. Загальна довжина шаблі складає 91 см, довжина клинка 75 см, ширина клинка - 3,1 см, кривина - 1,1 / 30. Вага шаблі разом 3 піхвою - 1400 г, без піхви -790 г.

При іiі виготовленні використовувалися такі матеріали як сталь, нікель, дерево, шкіра, застосовувалася техніка нікелювання та штампування. Шабля потрапила до ЛІМ з колекції Військовоісторичного музею м. Львова (Архів ЛІМ: № 3-1083).

Цілком очевидно, що у 20-30-х роках XX століття, тобто у період польської окупації Західної України, в експозиції та фондах Національного музею ім. короля Яна III перевага надавалася представленню зброї, озброєння, елементів військового спорядження військових підрозділів Польщі, щоби підкреслити мужність і героїзм поляків й, по можливості, замовчати або ж применшити роль українців у подіях 1920 року.

Р. Менкицький у своєму путівнику по Національному музею ім. короля Яна III (1936 року випуску), повідомляв, що зброю та озброєння польського війська періоду польсько-більшовицької війни 1920 року можна оглянути на третьому поверсі колишньої кам'яниці К. Корнякта у XI залі (Зброярні II), де знаходилося східне озброєння та зброя XVII століття, західноєвропейська 
зброя XIX століття, польська зброя часів наполеонівських воєн, Варшавського князівства, т. зв. конгресового королівства, повстань 1830 - 1831 та 1863 - 1864 років, часів Першої світової війни та подій 1918 - 1920 років (Mękicki, 1936: 58).

Так на вішаку № 33 у музейній експозиції демонструвалися польські шаблі кавалерії та піхоти з 1920 року, а між вішаками кавалерійські списи-піки (Mękicki, 1936: 68-69). У заскленій вітрині чотири штурмові шоломи французького зразка, зібрані після бою під Задвір'ям з полеглих польських вояків (Mękicki, 1936: 70).

Бій 17 серпня 1920 р. біля залізничної станції Задвір'я між польськими добровольчими підрозділами та загонами російської 1-ї Кінної армії під командуванням С. Будьонного відбулася на ближніх підступах до Львова й завершилася операційним успіхом польських збройних формувань. У бою під Задвір'ям поляки захопили кілька сотень полонених, значну кількість російської зброї, елементів озброєння, російські бойові прапори та ін.

Шоломи-каски, пошкоджені більшовицькими шаблями, належали воякам польського добровольчого батальйону під командуванням майора Романа Абрахама, загиблим 17 серпня 1920 р. під Задвір'ям. Національному музею ім. короля Яна III їх передали за наказом командира Малопольських відділів Добровольчої Армії полковника Чеслава Мачинського разом 3 дарчим листом від 22 жовтня 1920 року.

В інвентарній книзі № 9 фондової групи «Зброя» ЛІМ подано опис одного $з$ цих шоломів (№ 3-3735). В описі, між іншим, зазначено, що даний шолом-каска виготовлений у першій чверті ХX століття. Модель знаходилася на озброєнні французької армії, а в 1918 - 1920 роках - польської.

Вказано, що каска належала невідомому воякові з батальйону майора Р. Абрахама, який загинув у бою під Задвір'ям. Її тулія має нижній край відігнутий під тупим кутом й утворює криси, а спереду та ззаду - козирки, обведені округлим кантом. Спереду до тулії прикріплено овальний картуш 3 виштампуваним зображенням польського орла. Б. Мельник, складаючи опис предмета, зауважив, що «каска сильно пом'ята у кількох місцях (сліди ударів)» (Архів ЛІМ: № 3-3735).

До захисного озброєння даного періоду можна віднести також французькі шоломи-каски (№ 3-2748, 3-2749, 3-2756) часів Першої світової війни, що були на озброєнні польських військ у 
1918-1920 роках (Архів ЛІМ: № 3-2748, 3-2749, 3-2756). 3 них викликає зацікавлення каска під інвентарним номером 3-2756, яка належала польському воякові з армії генерала Юзефа Галлера. В інвентарній книзі «Dziennik nabytków muzeum narodowego im. króla Jana III» опис каски поданий під номером 1552. У ньому зазначено, що це сталевий французький шолом, використовуваний в армії Ю. Галлера (Dziennik nabytków muzeum narodowego im. króla Jana III, 1939: № 1552).

Сліди від шабельних ударів на захисних касках наглядно свідчать, що такі різновиди холодної рублячи-колючої зброї, як шабля і шашка активно використовувався учасниками війни 1920 р.

3 шабель, що були на озброєнні польських вояків, найбільшу увагу привертає до себе, знову ж таки саме через те, що це меморіальна річ, офіцерська шабля зразка 1861 року (№ 3-3731), яка належала поручнику Яну Казимиру Бодновському, узятому в російський полон 26 - 27 червня 1920 р. червоноармійцем 6 дивізії 1 Кінної армії РРФСР Свгенієм Матушевським. У 1958 році iï передав до ЛІМ сам учасник подій - на той час мешканець м. Житомира С. Матушевський.

Ця модель шаблі перебувала на озброєнні офіцерів австрійської, згодом австро-угорської армії упродовж 1861 - 1918 років. Її загальна довжина складає 101,3 см, а довжина клинка $-87 \mathrm{~cm}$ (Архів ЛІМ: № 3-3731). Пощерблений у кількох місцях шабельний клинок наглядно вказує на його бойове застосування.

Ще одним німим свідком боїв польсько-російського конфлікту 1920 р. стала шабля невідомого польського вояка 3 колекції ЛІМ за інвентарним номером 3-3730, знайдена у Рівненській області на полі поблизу села Клекотів, де у 1920 році відбувся бій між польськими підрозділами армії Ю. Галлера та Особливою бригадою 1-ї Кінної армії РРФСР.

Шабля виготовлена у 1917 - 1920 роках, має збірний характер. Ïї гард, можливо, від французької шаблі, а клинок - від австрійської офіцерської шаблі зразка 1904 року. Загальна довжина - 92,7 см, довжина клинка - 79,5 см (Архів ЛIМ: № 3-3730).

У 1921 р. командування VI корпусу Війська Польського передало на депозит (тимчасове зберігання) Національному музею ім. короля Яна III зброю часів Першої світової війни та подій 19181920 років (Мельник, 2006: 11). До цього депозиту належала, 
зокрема, й французька гвинтівка системи Гра-Кропачека, виготовлена у 1880 роках на зброярських заводах м. Сен-Ентьєн (Архів ЛІМ: № 3-3063).

Гвинтівка конструкції капітана французької армії Базилія Гра являла собою переробку під металевий патрон наявної на озброєнні французів однозарядної гвинтівки системи Антуана Шасспо. У 1878 р. до гвинтівки Гра додався підствольний магазин, розроблений австрійським майором Альфредом Кропачеком.

Гвинтівки системи Гра-Кропачека перебували на озброєнні колоніальних військ Франції, а в 1918 - 1920 роках - польських військ. Гвинтівка має номер «L26», заводський номер «P52230», клейма, на лівій стінці ствольної коробки є напис: «MANUFACTURE D'ARME (St. ETIENNE), M le 1874-1885». (Архів ЛІМ: № 3-3063).

Ще одним прикладом особливої турботи країн Антанти, головним чином Франції, про оснащеність польського війська, може служити французька гвинтівка системи Лебеля зразка 1886 року, виготовлена на військових заводах Шательро у 1889 р.

Нарізні магазинні гвинтівки системи Лебеля французька армія мала на озброєнні з 1886 р. Вони двічі модернізувалася. Такі гвинтівки використовувалися арміями багатьох держав. Окремі зразки надходили на озброєння й польського війська у 1918 - 1920 роках.

У гвинтівки круглий, нарізний ствол, на дульній частині якого є сегментовидна мушка з прямокутною базою, а зі споду прилив під багнет. Під стволом знаходиться трубковидний магазин. Ближче до казни - підйомний рамковий приціл з пересувним хомутиком і поділками від 1 до 24. На казенну частину нагвинчена ствольна коробка. Ствол кріпиться до ложі двома ложовими кільцями, переднє з яких має штир з плоскою голівкою, а заднє антабу.

Патронник позначений заводським номером «70931», є чотири випробувальні клейма і дата «МА С 1889». Затвор у гвинтівки поворотно-ковзний, 3 плоскою голівкою рукоятки, позначений номером «70931». На ствольній коробці, справа знизу, змонтовано важіль перевідника, а зліва на коробці стоїть напис: «MANUFACTURE D'ARMES | CHATELLERAULT Mle 1886 M93» («Військовий завод| Шательро 1886 рік M93» - П. А.). Ложа дерев'яна. Приклад приєднаний до ствольної коробки. На прикладі вибито номер «45467», на нижній стінці ствольної коробки А5373633 (Архів ЛIМ: № 3-3048). 
У радянську епоху подіям 1920 р. тоталітарний режим надавав важливого значення як компоненту, необхідній складовій радянської ідеологічної пропаганди. Так у путівнику по ЛІМу 1976 р. зазначалося, що у музейній експозиції «відвідувачі можуть оглянути різноманітну ручну зброю червоноармійців Першої Кінної армії, бойову тачанку з кулеметом системи «Максим»... Розділ доповнює картина художника М. Добронравова (1948р.), що зображує переможний бій Кінної армії з білопольськими військами під Задвір'ям (20 кілометрів від Львова) 17 серпня 1920 р.» (Цит. за: Багрій Р., Мельник Б., Свєшнікова I., 1976: 126).

Національний музей ім. короля Яна III у міжвоєнний період 3 тією ж самою пропагандистською метою, але уже для того, щоби вивищити польські звитяги, певне місце у музейній експозиції відводив трофейній російській зброї та іншим предметам (російсько-більшовицькими прапорами, відзнаками), пов'язаними 3 польсько-російським збройним конфліктом 1920 року.

Зокрема, в експозиції Музею 20-30-х років минулого століття демонструвалися: радянський металевий спис-піка 3 червоним прапорцем, російський револьвер системи «Наган», пошкоджений у бою під Задвір'ям 17 серпня 1920 р. вибухом гранати, більшовицькі прапори, здобуті поляками у 1920 р. біля Львова - прапор IX відділу радянської повітряної армії, прапор сибірського полку Червоної Армії РРФСР, прапор 1-ї Кінної армії РРФСР та ін. (Mękicki, 1936: 72).

Більш докладну інформацію про російсько-радянську трофейну зброю подають інвентарні книги. Так в інвентарній книзі «Dziennik nabytków muzeum narodowego im. króla Jana III» (Dziennik nabytków muzeum narodowego im. króla Jana III, 1939: № 1584), а також у книзі № 2 фондової групи «Зброя» ЛІМ (№3-443) знаходимо інформацію про кавалерійську солдатську шашку зразка 1881 р., яку в 1920 р. передало до збірки Національного музею ім. короля Яна III Управління львівського армійського арсеналу (Zarząd zbrojowni Wojsk Polskich). В описі даного предмета, складеному науковим працівником ЛІМ О. Перелигіною 22 жовтня 1979 р., зазначалося, що шашку виготовили у Росії на Златоустівському заводі у 1903 р.

Цей тип зброї використовувався російською царською, згодом російсько-більшовицькою кавалерією до 1927 року. Шашка має кородований та пощерблений клинок. Ї̈̈ загальна довжина складає 100,1 см, а довжина клинка - 86,5 см, кривина - 1,8 / 45. 
На п'яті клинка шашки стоїть клеймо військового заводу у Златоусті й дата «1903» (з лівого боку), а з правого - клеймо «Ш», клеймо в овалі, яке повторюється на обоймиці грифа та цифра «5». Гриф - дерев'яний, рубчастий по діагоналі. Має латунні обоймицю 3 клеймом «8 К» заводу в Златоусті, датою та голівкою у вигляді голови птаха з отвором під темляк (Архів ЛІМ: № 3-443).

На озброєнні російсько-більшовицьких угруповань звичайно ж була і вогнестрільна зброя, зокрема, досить зручні для кавалерії обрізи. Так, наприклад, трофейний російський обріз поляки здобули у боях під Баром 1920 р. Національному музею ім. короля Яна III його передав польський капітан, ад'ютант штабу Сильвестр Стрільчик-Висоцький (Dziennik nabytków muzeum narodowego im. króla Jana III, 1939: № 1576).

В інвентарному описі фондової групи «Зброя» ЛІМ даний предмет записаний під номером 3-2295 й визначений як обріз 3 круглим нарізним стволом, виготовлений на основі гвинтівки системи Мосіна. На патроннику стоїть клеймо «ИЖЕВСКИЙ ОРУЖЕЙНЫЙ ЗАВОД», дата випуску - 1916 рік, заводський знак, контрольні клейма та державне клеймо - двоголовий російський орел (повторюється на ствольній коробці). Ложа дерев'яна, укорочена, без прикладу, калібр - 7,62 мм (Архів ЛІМ: № 3-2295).

Подібним до попереднього, є трофейний російсько-більшовицький обріз, переданий Національному музею ім. короля Яна III IX секцією «Громадянської Легії» (Dziennik nabytków muzeum narodowego im. króla Jana III, 1939: № 1586).

В інвентарній книзі фондової групи «Зброя» предмет визначений як обріз, перероблений $з$ російської гвинтівки системи Мосіна (№ 3-2293). В описі зазначено, що ця зброя перебувала у користуванні вояка 1 Кінної армії РРФСР. На патроннику бачимо клеймо «ИЖЕВСКИЙ ОРУЖЕЙНЫЙ ЗАВОД» і дату - 1905 рік. Ложа дерев'яна, з рукояткою загнутою під кутом 90. 3 правого боку обріз має напівстертий напис «DAR LEGII OBYWATELSKIEJ» (Архів ЛІМ: № 3-2293).

Ще один трофейний російський обріз, перероблений 3 французької гвинтівки (№3-2294), теж знаходився на озброєнні вояка I Кінної армії РРФСР. Національному музею ім. короля Яна III (записаний під інвентарним номером 1584) цю зброю передало Управління львівського армійського арсеналу (Zarząd zbrojowni 
Wojsk Polskich) (Dziennik nabytków muzeum narodowego im. króla Jana III, 1939: № 1584). На патроннику стоять клейма, дата виготовлення - 1916 p. і заводський номер А4481, який повторюється на затворі та кришці магазину (Архів ЛIМ: № 32294).

До подібних трофейних обрізів відноситься й обріз вояка І Кінної армії РРФСР (№3-2296), перероблений 3 російської гвинтівки системи Мосіна зразка 1891 року, теж переданий Музею Управлінням львівського армійського арсеналу (Zarząd zbrojowni Wojsk Polskich). У нього круглий нарізний ствол. На патроннику стоїть клеймо «ИЖЕВСКИЙ ОРУЖЕЙЫЙ ЗАВОД», державне клеймо - російський двоголовий орел, яке повторюється на ствольній коробці. Обріз має повздовжньо-ковзний затвор, позначений заводським номером 109 868. Ложа укорочена, без прикладу з магазинною коробкою, позначеною заводським номером 27 091, калібр - 8 мм (Архів ЛІМ: № 3-2296).

Зараз у ЛІМі, періоду українських національно-визвольних змагань 1917 - 1921 років присвячена значна частина експозиції відділу «Музей визвольної боротьби України».

Висновки. Отже, короткий аналіз характерних особливостей предметів зброї та озброєння 3 колекцій Національного музею ім. короля Яна III та ЛІМу, здійснений у цій статті, дозволяє детальніше розглянути події польсько-російської війни 1920 року через призму вивчення окремих зразків зброї та озброєння учасників конфлікту.

Особливу зацікавленість викликає меморіальна зброя, яка у поєднанні 3 документальними та іншими джерелами, суттєво доповнює й поглиблює наші знання про цей збройний конфлікт сторічної давнини. Вважаємо, що тема $є$ перспективною й потребує подальших грунтовних досліджень.

\section{Використані посилання}

Архів Львівського історичного музею (Архів ЛІМ), м. Львів, ф. «Зброя». Кн. 2. Інв. №№ 3-443, 3-754.

Архів ЛІМ, м. Львів, ф. «Зброя». Кн. 3. Інв. № 3-1084.

Архів ЛІМ, м. Львів, ф. «Зброя». Кн. 5. Інв. №№ 3-2293, 3-2294, 3-2295, 3-2296.

Архів ЛІМ, м. Львів, ф. «Зброя». Кн. 7. Інв. №№ 3-2748, 3-2749, 3-2756, 3-3048.

Архів ЛІМ, м. Львів, ф. «Зброя». Кн. 8. Інв. № 3-3063.

Архів ЛІМ, м. Львів, ф. «Зброя». Кн. 9. Інв. №№ 3-3730, 3-3731, 3-3735.

Архів ЛІМ, м. Львів, ф. «Зброя». Кн. 10. Інв. № 3-4396. 
Багрій Р., Мельник Б., Свєшнікова І. (1976). Львівський історичний музей. Путівник. Львів. 250 с.

Кучерук В. (2010). Українська Галицька Армія: довідник. Львівський історичний музей. Київ. 408 с.

Литвин М., Науменко К. (1991). Історія галиџького стрілецтва, Львів, 200 с.

Мельник Б., Роман О. (1993). Каталог вогнепальної зброї. Пістолети $i$ револьвери. Львівський історичний музей. Львів. 64 с.

Мельник Б., Роман О. (2006). Колекиія зброї Львівського історичного музею. Скарби зброї XV-XVIII cm. 3 колекиї Львівського історичного музею. Каталог виставки. Лодзь. $131 \mathrm{c.}$

Dziennik nabytków muzeum narodowego im. króla Jana III. (1939). Lwów. №№ 1552, 1570, 1576, 1584, 1586.

Mękicki R. 1936. Muzeum narodowe im. kröla Jana III we Lwowie. Przewodnik po zbiorach. Lwőw. $130 \mathrm{~s}$.

\section{References}

Archive Lviv Historical Museum (Archive of LHM), Lviv, f. "Weapons". Book. 2. № 3-443, 3-754.

Archive of LHM, Lviv, f. "Weapons". Book. 3. № 3-1084.

Archive of LHM, Lviv, f. "Weapons". Book 5. № 3-2293, 3-2294, 3-2295, 3-2296.

Archive of LHM, Lviv, f. "Weapons". Book. 7. № 3-2748, 3-2749, 3-2756, 3-3048.

Archive of LHM, Lviv, f. "Weapons". Book. 8. № 3-3063.

Archive of LHM, Lviv, f. "Weapons". Book. 9. № 3-3730, 3-3731, 3-3735.

Archive of LHM, Lviv, f. "Weapons". Book. 10. № 3-4396.

Bagrij R., Melnyk B., Svehnikova I. (1976). Lviv historical museum. Guide-book. Lviv. 250 p. (ukr).

Kuheruк V. (2010). Ukrainian Galychyna Army: reference book. Lviv historical museum. Kyiv. 408 p. (ukr).

Lytvyn M., Naumenko K. (1991). History of galician shooters. Lviv. 200 p. (ukr).

Melnyk B., Roman O. (1993). Catalogue of shooting-iron. Pistols and revolvers. Lviv historical museum. Lviv. 64 p. (ukr).

Melnyk B., Roman O. (2006). Collection of weapon of the Lviv historical museum. Treasures of weapon XV-XVIII century from collection of the Lviv historical museum. Catalogue of exhibition. Lodz. 131 p. (ukr).

Dziennik nabytków muzeum narodowego im. króla Jana III. (1939). Lwów. №№ 1552, 1570, 1576, 1584, 1586. (pol).

Mękicki R. (1936). Muzeum narodowe im. kröla Jana III we Lwowie. Przewodnik po zbiorach. Lwów. 130 s. (pol).

\section{Prokip A.}

Myhalskyj Y.

SAMPLES OF WEAPONS, ELEMENTS OF WEAPONS DURING THE POLISH-RUSSIAN WAR OF 1920 FROM THE COLLECTIONS NATIONAL MUSEUM NAMED KING JAN III AND THE LVIV HISTORICAL MUSEUM

The events Polish-Russian war of 1920 assisted to substantial addition and enriching of collections at first the National museum the name of king Jan III in Lviv, 
and afterwards his successor - Lviv Historical Museum, by various objects, in particular, by a weapon, elements of armament, military accoutrement These objects can be conditionally divided into three groups: weapon and armament, related to Ukrainian military subdivisions, weapons, armament of Poland, weapons of Russianbolshevik invaders of period of war of 1920.

The publication examines in more detail the events of the Polish-Russian war of 1920, analyzes the characteristics of weapons and weapons of the conflict: cold steel (bayonets, sabers, checkers), firearms (rifles of various systems, revolvers), elements of protective weapons (helmets), which were used in the Active Army of the Ukrainian People's Republic, the Polish army, in the Russian-Bolshevik so-called "red" army.

Particular attention is paid to samples of memorial weapons belonging to soldiers of the Ukrainian (sword of Otaman Yaroslav Voevidka), Polish armies (sword of Lieutenant Jan Kazimir Bodnowski). Weapons and weapons originating from the sites of specific battles of the Polish-Russian war of 1920 (for example, the saber of an unknown Polish soldier found in the Rivne region near the village of Klekotiv, where in 1920 there was a battle between Polish units of Józef Haller and Special brigade of the 1st Cavalry Army of Russia, helmets were damaged by Russian swords of soldiers of the Polish volunteer battalion under the command of Major Roman Abraham, who died on August 17, 1920 in the battle near Zadvirya, trophy Russian cut obtained in the battles near Bar in 1920 and transferred named after King Jan III Captain, Adjutant of the Sylvester Strilchyk-Vysotsky).

Keywords: Museum, weapons, Polish-Russian war of 1920. 